\title{
BLOOD PLASMA FIBRINOGEN IN RHEUMATIC AND NON-RHEUMATIC CONDITIONS
}

\author{
BY
}

\section{A. J. MESTER}

A striking feature in many forms of rheumatic disease is the high sedimentation rate of the erythrocytes. The rate of fall of erythrocytes in plasma may be expressed as sedimentation rate (S.R.), or as suspension stability (S.S.). The S.R. (Westergren, Linzenmeier) is expressed by a figure indicating the fall of the column of the red cells in a $200 \mathrm{~mm}$. tube, while the S.S. is expressed as the height of the column of red cells as a percentage, a wider tube being used.

\section{Some Factors in Suspension Stability}

The altered S.S. in rheumatic conditions of the joints is characteristic as to both intensity and duration. In the case of rheumatoid arthritis the intensity is significant, because the duration is naturally parallel to the chronicity of this condition. In rheumatic fever the greatly altered intensity is usually of short duration, but it takes a long time before it reaches normal values. Generally we may find an altered sedimentation rate several weeks after complete disappearance of subjective and objective signs and symptoms. The same also applies to the initial stage of rheumatic affections, especially in children, where insignificant, vague complaints may be accompanied by a high sedimentation rate. Thus the insidious character of the rheumatic process may be revealed initially by the altered S.S.

The S.S. is a complicated process, both physically and chemically. Physically it is an outcome of cohesive and repulsive forces acting on the suspended erythrocytes in a viscous fluid medium. The composition of the fluid medium is the most important factor, and the dominant part is played by the blood proteins. The "fastest" protein is fibrinogen, the second " fast" is euglobulin, later pseudoglobulin. The "slow" proteins are the albumins, especially globoglycoid. Clementina M. Gordon and J. R. Wardley have shown that the albumins slow the S.R. globoglycoid more than crystalbumin and seromucoid. The S.R. thus depends on the relative proportions of fibrinogen, globulins, and albumins, and is also affected by the volume of the erythrocytes, therefore the red cell count is important. Although some workers apply a correction for anaemia or polycythaemia, most disregard this factor. In tuberculosis institutions and in rheumatic hospitals, whose patients include a considerable percentage of anaemic conditions due to the basic disease, the correction for anaemia is usually not carried out. Therefore the S.S. method, as described by D. H. Collins et al., in which the estimation of the cell volume of the red blood corpuscles is adopted as a routine, is to be preferred.

In this method the percentage volume of the hypophase-red cell layer-is determined at halfhourly intervals for 2 hours in a $5 \mathrm{c.cm}$. graduated centrifuge tube, containing $5 \mathrm{c.cm}$. of venous blood with a minimal amount $(1 \mathrm{mg}$. per $1 \mathrm{ml}$. blood) of potassium oxalate. The most important is the first hour reading as in Westergren's method, which includes the phase in which the rate of fall of rouleaux is greatest. The simultaneous haematocrit estimation in a $100-\mathrm{mm}$. long, narrow tube, like Wintrobe's haematocrit tube, gives the percentage volume of the packed red cells (P.C.V.). The S.S. readings are corrected to 42 per cent. cell volume, this value being used as a standard for both men and women. The appropriate correction is added if the C.V. is below 42 per cent. and subtracted if it is above this figure, the magnitude being determined by the difference between 42 per cent. and the observed C.V. The approximate comparative values between S.R. and S.S. are given in Table 1 .

\section{Blood Fibrinogen}

The importance of the blood fibrinogen in health and disease has received much attention, especially in the liver and the blood, and in rheumatic conditions. Blood fibrinogen is thought to come from the liver. Some authors believe that a certain amount may be held in reserve in the intestinal tract. Fibrinogen constitutes 3-6 per cent. of the total blood proteins, representing $250-400 \mathrm{mg}$. per 100 $\mathrm{ml}$. plasma. It is the most labile protein in the blood; it regenerates very quickly (in a few hours) as opposed to other blood proteins, which re-

TABLE 1

\begin{tabular}{|c|c|c|c|c|c|c|c|c|c|c|c|c|c|c|c|c|c|c|c|c|}
\hline \multicolumn{21}{|c|}{ APPROXIMATE COMParative Val } \\
\hline Westergren * & 10 & 20 & 30 & 40 & 50 & 60 & 70 & 80 & 90 & 100 & 110 & 120 & 130 & 140 & 150 & 160 & 170 & 180 & 190 & Westergren \\
\hline S.S. † & 95 & 90 & 85 & 80 & 75 & 70 & 65 & 60 & 55 & 50 & 45 & 40 & 35 & 30 & 25 & 20 & 15 & 10 & 5 & S.S. \\
\hline
\end{tabular}


generate more slowly. The quick response of blood fibrinogen to infections, intoxications, and tissue destruction takes place in persons whose liver cells are not extensively damaged. In severe damage of the liver, as in phosphorus or chloroform poisoning, the blood fibrinogen quickly, sometimes in few hours, drops to very low level. It returns to normal values only in case of regeneration of the liver cells. In severe primary anaemias, in leukaemias, in haemolytic jaundice, and in banal icterus the blood fibrinogen is low. In the fasting state and when the diet is uniform, the blood fibrinogen maintains a fairly stable level, and in health the physiological blood-fibrinogen fluctuations are small. In the presence of an infection, intoxication, or any condition causing tissue destruction, an increase in blood fibrinogen will soon occur in an individual with a healthy liver even with a slight secondary anaemia. According to Kisch a two-fold connexion exists between the blood fibrinogen and the reticuloendothelial system (R.E.S.). (1) The R.E.S. is supposed to produce the material for the fibrinogen. (2) Extensive damage to liver cells impairs the fibrinogen production. The important rôle of the blood fibrinogen in the mechanism of blood clotting is known.

Because of the changes in sedimentation rate in rheumatic diseases it seemed desirable to investigate the fibrinogen values in the different types. Two points may first be noted: (1) In the early stage of acute rheumatism and rheumatoid arthritis there is to be found in the affected parts a great mass of precipitated fibrin and fibrinoid substances-Klinge's "fibrinoide Verquellung." (2) The predominant rôle of the fibrinogen in the S.R. The marked alteration in the sedimentation rate in rheumatic fever and rheumatoid arthritis, non-purulent diseases, deserves special attention. A satisfactory explanation of the increased fibrinogen production in rheumatic fever and in rheumatoid arthritis is not yet forthcoming. The rheumatic agent may so affect the liver as to stimulate the production of fibrinogen without "reaching a stage which would depress this function; or it may be that in rheumatic joint conditions the extent of tissue destruction is great; or some individuals may be predisposed to an abnormal production of fibrinogen, reacting to a supposed specific or nonspecific agent, and thus be prone to rheumatic joint conditions?

\section{Present Investigation}

In an attempt to throw light on these problems, the blood fibrinogen, the suspension stability, and the packed red cell volume were estimated in 220 patients attending the Devonshire Royal Hospital. The blood plasma fibrinogen was estimated by the gravimetric method of Cullen-van Slyke in $2 \mathrm{ml}$. of plasma, and the results recorded are ash-free fibrinogen in $\mathrm{mg}$. per $100 \mathrm{ml}$. plasma. This method gives as a normal value $250-400 \mathrm{mg}$. per $100 \mathrm{ml}$. The S.S. and hematocrit estimations were made by the method of Collins et al. These 220 patients comprise:
Rheumatoid arthritis, 53. Spondylarthritis ankylopoietica, 10.

Osteoarthritis, 37.

Subacute rheumatism, 20.

Chronic muscular rheumatism, 38.

Traumatic arthritis, 13.

Sciatica, 7.
Unclassified conditions, 8.

TABLE 2

\begin{tabular}{|c|c|c|c|c|c|}
\hline \multicolumn{6}{|c|}{$\begin{array}{l}\text { RHEUMATOID ARTHRITIS } \\
\text { Mean of Fifty-Three Cases }\end{array}$} \\
\hline & $\begin{array}{l}\text { Packed cell } \\
\text { volume } \\
37\end{array}$ & $\begin{array}{c}\text { Corrected } \\
\text { S.S. } \\
71\end{array}$ & \multicolumn{2}{|c|}{$\begin{array}{l}\text { Fibrinogen } \\
\text { mg. per } 100 \mathrm{ml} . \\
520\end{array}$} \\
\hline \multicolumn{6}{|c|}{ Statistical Correction for Fibrinogen } \\
\hline \multicolumn{2}{|r|}{$\begin{array}{c}\text { Range } \\
340 \text { to } 700\end{array}$} & $\begin{array}{c}\text { Standard } \\
\text { deviation } \\
83 \cdot 24\end{array}$ & $\begin{array}{cc}\begin{array}{c}\text { Coefficient } \\
\text { of } \\
\text { variation } \\
16 \cdot 00\end{array} & S \\
& \end{array}$ & $\begin{array}{l}\text { Standard } \\
\text { error } \\
\text { of S.D. } \\
8.08\end{array}$ & $\begin{array}{c}\text { Probable } \\
\text { error } \\
5.44\end{array}$ \\
\hline \multicolumn{6}{|c|}{$\begin{array}{c}\text { SPONDYLITIS ANKYLOPOIETICA } \\
\text { Mean of Ten Cases }\end{array}$} \\
\hline \multicolumn{2}{|c|}{$\begin{array}{c}\text { Suspension } \\
\text { stability } \\
\mathbf{7 0 \cdot 7}\end{array}$} & $\begin{array}{l}\text { Packed cell } \\
\text { volume } \\
43.6\end{array}$ & $\begin{array}{l}\text { Corrected } \\
\text { S.S. } \\
\mathbf{6 8 . 4}\end{array}$ & \multicolumn{2}{|c|}{$\begin{array}{l}\text { Fibrinogen, } \\
\text { mg. per } 100 \mathrm{ml} . \\
559\end{array}$} \\
\hline \multicolumn{6}{|c|}{ Statistical Correction for Fibrinogen } \\
\hline $\begin{array}{l}\text { Mean } \\
559\end{array}$ & $\begin{array}{c}\text { Range } \\
460 \text { to } 700\end{array}$ & $\begin{array}{c}\text { Standard } \\
\text { deviation } \\
86.42\end{array}$ & $\begin{array}{c}\text { Coefficient } \\
\text { of variation } \\
15 \cdot 46\end{array}$ & $\begin{array}{l}\text { Standard } \\
\text { error } \\
24 \cdot 33\end{array}$ & $\begin{array}{l}\text { Probable } \\
\text { error } \\
16.41\end{array}$ \\
\hline \multicolumn{6}{|c|}{ OSTEO-ARTHRITIS } \\
\hline \multicolumn{4}{|c|}{ 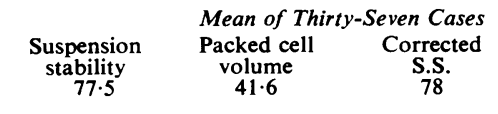 } & \multicolumn{2}{|c|}{$\begin{array}{l}\text { Fibrinogen, } \\
\text { mg. per } 100 \mathrm{ml} \text {. } \\
381\end{array}$} \\
\hline \multicolumn{6}{|c|}{ Statistical Correction for Fibrinogen } \\
\hline $\begin{array}{c}\text { Mean } \\
381\end{array}$ & $\begin{array}{c}\text { Range } \\
220 \text { to } 580\end{array}$ & $\begin{array}{c}\text { Standard } \\
\text { deviation } \\
76.93\end{array}$ & $\begin{array}{c}\text { Coefficient } \\
\text { of variation } \\
20 \cdot 18\end{array}$ & $\begin{array}{c}\text { Standard } \\
\text { error } \\
14 \cdot 50\end{array}$ & $\begin{array}{c}\text { Probable } \\
\text { error } \\
\mathbf{9 . 7 7}\end{array}$ \\
\hline \multicolumn{6}{|c|}{$\begin{array}{l}\text { Subacute Rheumatism } \\
\text { Mean of Twenty Cases }\end{array}$} \\
\hline & S.S. & $\begin{array}{l}\text { P.C.V. } \\
41 \cdot 7\end{array}$ & $\begin{array}{c}\text { Corrected } \\
\text { S.S. } \\
\mathbf{7 8}\end{array}$ & \multicolumn{2}{|c|}{$\begin{array}{l}\text { Fibrinogen } \\
\text { mg. per } 100 \mathrm{ml} \text {. } \\
413.5\end{array}$} \\
\hline
\end{tabular}

Statistical Correction for Fibrinogen

$\begin{array}{cccccc}\text { Mean } & \text { Range } & \text { S.D. } & \text { C. of F. } & \text { S.E. } & \text { P.E } \\ 413.5 & 230-670 & 69.64 & 16.83 & 11.04 & 7.44\end{array}$

Chronic Muscular Rheumatism Mean of Thirty-Eight Cases $\begin{array}{cccc}\begin{array}{c}\text { Suspension } \\ \text { stability }\end{array} & \begin{array}{c}\text { Packed cell } \\ \text { volume }\end{array} & \begin{array}{c}\text { Corrected } \\ \text { S.S. }\end{array} & \begin{array}{c}\text { Fibrinogen. } \\ \text { mg. per } 100 \mathrm{ml} .\end{array} \\ \mathbf{4 3} & \mathbf{4 6 8 . 8 5} & \mathbf{8 6} & \mathbf{4 4 8 . 8}\end{array}$

Statistical Correction for Fibrinogen

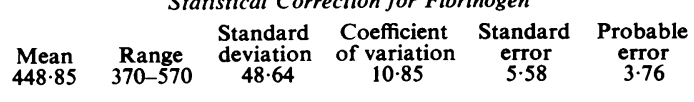

Traumatic Muscle affections Mean of Twelve Cases

\begin{tabular}{|c|c|c|c|c|}
\hline $\begin{array}{c}\text { Suspension } \\
\text { stability } \\
92 \cdot 5\end{array}$ & $\begin{array}{r}\text { Packed } \\
\text { volur } \\
42\end{array}$ & $\begin{array}{l}\text { I cell } \\
\text { me }\end{array}$ & $\begin{array}{l}\text { orrected } \\
\text { S.S. } \\
92\end{array}$ & $\begin{array}{l}\text { Fibrinogen, } \\
\text { mg. per } 100 \mathrm{ml} \text {. } \\
345 \cdot 7\end{array}$ \\
\hline \multicolumn{5}{|c|}{$\begin{array}{c}\text { CHRONIC Gout } \\
\text { Mean of Ten Cases }\end{array}$} \\
\hline $\begin{array}{l}\text { spension } \\
\text { tability } \\
72 \cdot 4\end{array}$ & $\begin{array}{l}\text { Packed cell } \\
\text { volume } \\
43.7\end{array}$ & $\begin{array}{c}\text { Corrected } \\
\text { S.S. } \\
69.1\end{array}$ & $\begin{array}{l}\text { Fibrinogen, } \\
\text { mg. per } \\
100 \mathrm{ml} . \\
466\end{array}$ & $\begin{array}{l}\text { Blood uric } \\
\text { acid, mg. } \\
\text { per } 100 \text { c.c. } \\
5.43\end{array}$ \\
\hline
\end{tabular}

\section{Discussion}

SPONDYLARTHRITIS ANKYLOPOIETICA

The plasma fibrinogen value in this disease affecting young men, is higher than in rheumatoid arthritis, $-559 \mathrm{mg}$. as compared with $520 \mathrm{mg}$. mean-but the difference is " not significant." 


\section{OSTEOARTHRITIS}

In pure uncomplicated cases the S.S. and blood fibrinogen are within normal limits but some patients show both lowered S.S. and increased fibrinogen. This may be attributed to several complications: it may be a banal, ordinary inflammation from small infractions as a result of microtraumata in one or more affected joints (e.g. bilateral osteoarthritis of the hip-joints, or a superimposition of rheumatoid arthritis; or vice versa it may be a superimposed osteoarthritic process on a still active rheumatoid process. Complicated cases of osteoarthritis of this kind are not infrequently met with.

\section{Subacute Rheumatism}

Patients in this group show great variety in the activity of the disease: some have had only one attack as far as 14 years back, while others have had relapses recently. Hence the great standard deviation. All these patients have rheumatic heart disease.

\section{Chronic Muscular Rheumatism}

In this group the most striking results were found: an increased blood fibrinogen in patients with normal S.S.; the mean for fibrinogen being $448.85 \mathrm{mg}$. per $100 \mathrm{ml}$. plasma, with a probable error of 3.76 , is definitely increased. The diagnosis of chronic muscular rheumatism was based not only on the history given by the patient, but also clinically by the presence of objective signs and symptoms. The statements of the patients were carefully scrutinised and the reliability checked. On examination objective signs were found such as muscle thickenings, circumscribed and well-defined areas of tenderness or muscle spasm, etc. The fact that in these patients the blood fibrinogen is increased where the S.S. is normal deserves to be stressed, as such a discrepancy was not found in any other condition here discussed. This discrepancy may throw some light on the nature of chronic muscular rheumatism, because, after careful exclusion of other possible factors leading to an increased blood fibrinogen, it supports the belief of English clinicians as to the rheumatic aetiology of chronic muscular ailments. There are, of course, muscular pains of a different aetiology, as gout, gonorrhoea, etc., but these represent a small fraction in the number of chronic muscular sufferers, and this aetiology will be detected in the course of careful examination.

If a rheumatic aetiology for these chronic muscular affections is accepted, gold treatment might be adopted as a natural corollary. Taking into consideration the leniency of the process both in the clinical picture and in the biological findings, I would suggest small doses of gold, both for each individual dose and for the whole course. Having diagnosed chronic muscular rheumatism in cases in which these are no contraindications (skin, kidney, liver affections, etc.) I adopt as the initial dose $0.005 \mathrm{~g}$. of a gold compound containing approxi- mately 50 per cent. metallic gold in watery solution (myocrisin) and increasing slowly to $0.05 \mathrm{~g}$. for a dose in 7-days' intervals, the total for a course being $0 \cdot 25$ of gold salt-i.e. $0 \cdot 125 \mathrm{~g}$. of gold.

This phenomenon of a normal S.S. with a raised blood fibrinogen in chronic muscular rheumatism may be due to the interplay of other factors determining the S.S., possibly inhibition by albumins, or perhaps due to the tissue reactivity of the muscles.

\section{Chronic Articular Gout}

The patients in the active stage show a low S.S. and increased blood fibrinogen. All these patients have had increased blood uric acid. The clinical and radiological findings were in conformity with the diagnosis.

\section{Sciatica}

This may be also of rheumatic aetiology, although probably only in a small percentage, but the number of observations was too small to allow any conclusions being drawn.

\section{OTHER CONDITIONS}

Traumatic joint-and-muscle affections, static conditions (flat feet), endocrinogenic disseminated pains -all show uniformly a normal S.S. with a normal blood fibrinogen.

\section{Conclusions}

The blood fibrinogen estimations may be of additional diagnostic value in cases of rheumatic conditions, especially in chronic muscular rheumatism, when the S.S. is normal. The active rheumatic affections of joints and muscles in patients with a healthy liver and normal blood, or only with slight secondary anaemia, provoke an increased blood fibrinogen. The increased blood fibrinogen with normal S.S. in chronic muscular rheumatism presents an indication for gold treatment in low doses. There is not sufficient evidence to support the view that liver function is impaired in rheumatic sufferers, their response to the fibrinogen-creating stimulus being normal.

I desire to express my indebtedness to Dr. C. W. Buckley for his suggestions and to Mr. Joseph Race, biochemist to the Devonshire Royal Hospital, for much valuable help and kindness.

I would also express my appreciation to the Polish Board of Education for a grant.

\section{REFERENCES}

Buckley, C. W. (1938). Arthritis, Fibrositis, and Gout, H. K. Lewis \& Co., London.

Collins, D. H., Gibson, H. J., Race, J., and Salt, G.B. (1939). Ann. rheumat. Dis., 1, 333 .

Foster, D. P., and Whipple, G. H. (1922). Amer. J. Physiol., 58, 379 and $393,407$.

Gordon, Clementina, M., and Wardley, J. R. (1943). Biochem. J., 7, 393.

Isaac-Krieger, K., and Hiege, A. (1923). Klin. Wschr., 2, 1067.

Kisch, F. (1923), Klin. Wschr., 2, 1452.

McLester, J. S. (1922). J. Amer. Med. Ass., 79, 17

Ponder Eric. Hematocrit Method.

(1944). Sedimentation in The Year Book Pblrs. Inc. Chicago Year Book of Physical Medicine, pp. 597, 1408.

Race, J (1929). 